\title{
Interpolations of class, "race", and politics
}

\author{
Denmark's Jyllands-Posten and its coverage \\ of Greek national elections during the "Greek crisis"
}

\author{
Yiannis Mylonas ${ }^{\mathrm{I}}$ \& Matina Noutsou ${ }^{\mathrm{II}}$ \\ I School of Media, National Research University Higher School of Economics, Moscow, Russia \\ II Department for the Study of Religions, Masaryk University, Brno, Czech Republic
}

\begin{abstract}
This article focuses on the ways in which the Danish liberal mainstream press covered events related to the so-called Greek crisis. In particular, we examine the coverage of the different Greek national elections that took place during the Greek crisis years (2010-2019) by Jyllands-Posten $(J P)$, a popular Danish daily newspaper. Qualitative content analysis is deployed to study a corpus of 70 news and editorial articles published by $J P$ on the aforementioned topic. Our analysis highlights the existence of three main interrelated themes in JP's constructions of the Greek elections: a moralist, a culturalist, and a technocratic/ anti-leftist theme. These themes are theorised through the use of relevant theory on class cultures and politics today.
\end{abstract}

Keywords: Greek crisis, liberalism, technocracy, anti-communism, Orientalism

\section{Introduction}

In this article, we study the mainstream media representations of the so-called Greek crisis in the Danish public sphere. This specific study continues our previous work (Mylonas \& Noutsou, 2018) on this understudied topic, as far as Scandinavian media is concerned. Critical scholars (e.g., Ervedosa, 2017) have generally studied German media coverage of the Greek, or eurozone crisis as well as that of Greek media (Kostopoulos, 2020 ) and the media from the Anglophone world (Bozatzis, 2016; Ojala \& Harjuniemi, 2016). Not much has been written, however, about the Scandinavian case. Hence, the study of the Danish public discussion on the European Union (EU), the eurozone crisis, and the European periphery overall, could cast more light on the broader eurozone crisis publicity that developed across Europe.

Additionally, although the racist aspects of Greek crisis media practices have been stressed by researchers (e.g., Bozatzis, 2016; Ervedosa, 2017), the class dimension of such practices has not been adequately studied. The Greek crisis, its wide publicity, and its political repercussions in the EU offers the opportunity to study the possible intertwining of race and class in the economic crisis context.

Mylonas, Y., \& Noutsou, M. (2021). Interpolations of class, "race”, and politics: Denmark's Jyllands-Posten and its coverage of Greek national elections during the "Greek crisis". Nordicom Review, 42(S3), 56-70. https://doi.org/10.2478/nor-2021-0026 
The Northern and Western media framing of Greece is stereotypical, associated with Orientalist tropes constructing Greece as a quasi- or non-European exotic space specifically favourable for mass summer holidays (Buck-Morss, 1987; Plantzos, 2012; Panagiotopoulos \& Sotiropoulos, 2020). Pelt's (2019) study of Danish media's coverage of Greece since the birth of the modern Greek state (1832) showed that the meanings defining Greece in the Danish public sphere are produced by hegemonic Western-centric recurrent themes.

The research is based on the study of a popular Danish liberal daily, ${ }^{1}$ Jyllands-Posten $(J P)$. First published in $1871, J P$ ranked as the third most popular newspaper in Denmark for the first half of 2019 (Statista, 2019). JP is owned by JP/Politikens Hus A/S, a media conglomerate that owns different media in both Denmark and Sweden. We chose $J P$ for this study due to its popularity, identity, and genre: a mainstream liberal newspaper of a core EU state. The focus on a liberal newspaper is crucial, because liberalism is currently the hegemonic ideological framework marking the norms of social and politicoeconomic life in the EU and beyond (Mondon \& Winter, 2020).

\section{Theoretical anchoring}

The theoretical points of departure for this study are 1) the critique of the Greek crisis and its hegemonic ${ }^{2}$ meaning construction by EU politicians, pundits, and mass media, 2) the uneven, core-periphery relations in the EU, 3) the critique of liberalism, and 4) the association between class and race.

The so-called Greek crisis emerged at the end of 2009 as part of the global financial crisis that erupted in the US in 2008, and officially ended in August 2018, when the third "Memorandum of Agreement" $(\mathrm{MoU})$ - the programme that dictated the neoliberal austerity reforms demanded by Greece in return for credit - was concluded. Neoliberal austerity regimes were imposed in Greece by the European "troika" (an institutional framework comprised of the European Central Bank, the European Commission, and the International Monetary Fund) and the different Greek governments to presumably avoid bankruptcy, reduce Greece's budget deficits, and make its economy competitive. The specific reform programmes were harsh, as they "included about 22.5 structural measures to be applied per year, compared to 8.5 per year in 2010 in the IMF programs" (Roos, 2019: 240), amounting to 18 per cent of Greece's gross domestic product. Austerity regimes brought about a massive decline in the living standards of the middle and lower classes in Greece, increased unemployment levels and inequality, and triggered further recession.

The specific policies were publicly legitimised through authoritative discourses articulated by established European politicians (e.g., Angela Merkel, Mario Draghi, and José Manuel Barroso), economists, and pundits who constructed the Greek crisis as a sui generis and "self-inflicted" case supposedly caused by the corrupt and irresponsible behaviour of the Greek citizens, as well as a largely dysfunctional state that underwent "reckless borrowing and spending" (Sotiropoulos et al., 2013: 186; Doudaki \& Boubouka, 2020; Kutter, 2020). Critical media studies (Mercille, 2013; Jacobsson, 2018; Basu, 2018) have found that the mainstream media coverage of the global economic crisis (in the EU, the US, and elsewhere) reproduced elitist interpretations and downplayed explanations that could highlight the systemic dimensions of the phenomenon. Through a process called "Greek-bashing" (Bickes et al., 2014), mainstream media everywhere 
produced a "Greek crisis" spectacle, depicting the Greek people (mostly those belonging to the working classes) as guilt-ridden for deceiving a somewhat benign EU and hardworking "European taxpayers" (Stamou, 2018; Kutter, 2020) while living "beyond their abilities". Nikolopoulou and Cantera (2016: 4) argue the following:

Factors such as the financial aid that was given to the private banking institutions, that is, the socialisation of the losses they [the banks] suffered due to their private management choices, were never conceptualised as a cause of the "debt crisis", although the country [Greece] had to borrow money for their recapitalisation; instead, they were represented as necessary and natural moves, directed at saving the country [Greece] itself.

Overall, Ojala and Harjuniemi (2016) demonstrated that the eurozone crisis (with the Greek crisis as its epicentre) was an opportunity for the public legitimation of neoliberal austerity policies in Europe. In this way, the pro-austerity media coverage solidified the hegemony of Germany as the most politically and economically strong state in the EU, spreading its message for the "necessity" of ordoliberal ${ }^{3}$ reforms in the eurozone.

Although Denmark is a non-eurozone EU member, it is one of the EU's "core" states of the North, all of which bear decisive influence on the general policy frameworks of the EU (Sepos, 2016). Furthermore, though generally understood as a socially and politically progressive state, during the last decades, scholars (Bolt, 2011) have observed the growth of political and social conservatism in Denmark, through the tightening of anti-migration laws and "integration" policies, the rise of xenophobia, and the development of a neoliberal "common-sense" (Stahl, 2019), as neoliberal reforms corrode the social-democratic foundations of the Danish society.

Though historically related to different political trajectories linked to both the left and right (Crouch, 2011), in the post-Cold War global setting, liberalism is decisively defined by neoliberal "free market" economics. Moreover, in recent years, liberalism has also come to be narrowly shaped by conservative, Western-centric, and increasingly xenophobic tropes, with critics framing such trends as "illiberal liberalism" (Lindekilde, 2014), "liberal racism", and "reactionary democracy" in a context where far-right agendas are becoming mainstream (Mondon \& Winter, 2020). In this regard, $J P$ became globally known for reproducing a series of offensive illustrations mocking Muhammed in 2005, a case that proved such illiberal liberalism - or liberal racism - theses (Lentin \& Titley, 2011).

Research has critically addressed the development of such illiberal trajectories in Denmark, with special attention paid to the ways the media contribute to these phenomena (Farkas \& Neumayer, 2020; Lentin \& Titley, 2011; Yilmaz, 2016). The class dimension of liberal racism, however, remains understudied. Racism is an organic part of the social hierarchies that form capitalist societies. In its different variations, racism provides a meritocratic basis to legitimise the capitalist division of labour, established privileges, and class hierarchy (Balibar \& Wallerstein, 1991). Further, as work and private property form the core "universal" values of the bourgeois ideology (Althusser, 2014: 43), the racialised Others are not entitled to the recompenses of the Western liberal bourgeois states, such as sociopolitical rights and consumerist lifestyles. Work and private property are crucial in the making of classed selves (Skeggs, 2003), as they bear a moral force upon the modern subject inhabiting societies defined by the capitalist mode of production. A failed work ethos, as demarcated by the capitalist mode of production 
(in its different variations), means profligacy and self-indulgence. Hence, the claiming (through neoliberal reforms) of the assets and property of the idle, the indebted, and the bankrupt can be legitimised on such grounds. Thus, bourgeois morality publicly legitimises dispossession processes of subjects or states deemed as failed.

\section{Research aims and method}

This study aims to 1) shed light on the Danish public discussion of the Greek crisis as it appears in its mainstream liberal press, while understanding Denmark to be a core EU state, and 2) explore the politics behind the representation of the Greek crisis and events related to it through their association with the discursive-ideological underpinnings of media content.

Newspapers form a particular kind of news media genre, constructing public opinion and reproducing ideological assumptions. This does not mean that the mainstream media in general are mere mouthpieces of authority, as, often, controversy, polyphony, and opposition also exist in such media content. Nevertheless, the structural biases of daily news media production should not be underestimated. Critical media research (van Dijk, 1988) has shown that, despite claims of the objectivity and plurality of content, newspapers represent a specific type of discourse that includes different textual genres and reproduces particular structures of social power. News production overall is "determined by powerful professional and social ideologies and organizational routines" (van Dijk, 1991: 40). The ideological role of the news is often concealed in daily news reporting, because news reporting may appear "neutral", impersonal, and unsophisticated. Editorial articles, however, are more opinionated and thus more openly ideological, even though $J P$ (like other newspapers) proclaims distance from its editors' opinions.

The events we chose for this study were the different Greek national elections that took place during the Greek crisis decade (2010-2019). These elections marked important moments of political contestation between rival political forces, in which neoliberal austerity was openly challenged by counter-hegemonic politics. The April 2012 and June 2012 elections occurred after several months of anti-austerity protests in Greece and represented the escalation of the previously small left-wing party Syriza (the Coalition of the Radical Left) to the main oppositional party in the Greek parliament, advocating for an anti-neoliberal, social democratic agenda. After the January 2015 elections, a Syriza-led, anti-austerity coalition government was elected. The September 2015 elections came after Syriza's succumbing to the neoliberal demands of the EU for the continuation of austerity policies. Then, the July 2019 elections meant the return to power of the conservative New Democracy (ND), which holds an authoritarian neoliberal agenda (Fabry \& Sandbeck, 2019).

A total number of 70 news and opinion articles from $J P$, covering the five national Greek elections, were analysed in this study. The empirical corpus consisted of 56 news/ report articles, 3 opinion articles, and 9 leading editorial articles. More specifically, we studied the following:

- Seven articles published between 24 April and 16 May 2012 (6 news/report articles and 1 leading editorial article) covering the 6 May 2012 national elections. The main themes appearing were the following: the Greek debt crisis was self-caused due to 
Greek irresponsibility; (austerity) reforms are a correct policy framework; the bailout loans provided to Greece are a case of European solidarity; Greece needs an economic development strategy; a potential exit of Greece from the eurozone will also mean Greece's exit from the EU; a possible Greek exit from the eurozone may be positive for the tightening of fiscal policy in the eurozone; and the crisis in Greece is bringing about a rise in unemployment, immigration, and poverty as well as the election of the far right "Golden Dawn" to the Greek parliament.

- Eighteen articles published 8-23 June 2012 (16 news/report articles and 2 leading editorial articles) covering the national elections of 12 June 2012. The main themes were the following: a possible Syriza victory may threaten the eurozone and the global economy overall due to the stress it can cause for financial markets; Greece is unwilling to reform and make its economy competitive; Greece has widespread corruption; the Greek crisis is self-inflicted; the Syriza leader, Alexis Tsipras, is a dangerous politician; the vote for Syriza is a catastrophic protest vote; Greece needs stability; and the re-election of ND may not offer many prospects for Greece, but it is still better than Syriza.

- Eighteen articles published between 6 January and 19 February 2015 (11 news/report articles, 2 opinion articles, and 5 leading editorial articles) covering the 25 January 2015 national elections. The main themes were the following: a Syriza election represents a far-left challenge to the EU; Greece is irresponsible, ungracious, immature, and overall is substantially different from Europe; and Greece has high unemployment and poverty rates.

- Nineteen articles published 6-23 August 2015 (18 news/report articles and 1 leading editorial article) covering the 20 September 2015 national elections. The main themes were the following: the Greek voters are exhausted and lack of enthusiasm and expectations for the elections; the agendas of the rival parties, regarding their intention to implement the EU's reforms, collide; the far-left Syriza failed to implement an anti-austerity agenda; Greece needs stability to implement reforms; the victory of Syriza is positive because Tsipras signed an austerity memorandum with the European troika and is able to contain anti-austerity protests; the reforms are a challenge for Greece's Europeanisation; and the 2015 refugee crisis and the influx of migrants and refugees to Europe through Greece form an additional challenge to Greece and Europe.

- Eight news/report articles published between 6 June and 10 July 2019 on the national elections of 7 July 2019. The main themes were the following: the elections' battle has a pragmatic (non-ideological) dimension; ND has a business and reform-friendly agenda; Syriza was successful in following the EU's dictates; Greece is nepotistic; and Greece's unemployment rates remain high.

The method of analysis that followed was that of qualitative content analysis. The articles studied were read twice ${ }^{4}$ and manually coded in two cycles of coding (Saldaña, 2011); the first cycle consisted of a general and descriptive mode of coding, where broad categories were assigned to clusters of issues analysed, often by using specific words found in the articles analysed (see Table 1). In the second cycle of the analysis, we developed the main themes among $J P$ 's coverage of the different election periods 
examined. The second cycle of coding consisted of the creation of broad, theoretically informed thematic categories, organised into relevant concepts critically reflecting the main ideological positions expressed in $J P$ (Saldaña, 2011). These thematic categories generalise the patterns of similarity and frequency (Saldaña, 2011) found in JP's coverage of the Greek crisis.

\section{Table 1 Examples of first-cycle coding during the analysis of JP's articles}

\begin{tabular}{|c|c|}
\hline Excerpts & $\begin{array}{l}\text { 1st cycle of coding: general/ } \\
\text { descriptive themes }\end{array}$ \\
\hline $\begin{array}{l}\text { [The] taxpayers in the other euro area countries, together with the IMF, } \\
\text { had to step into the role of economic lifeguards. (Jyllands-Posten, "Greek } \\
\text { goodbye", 2015, January 27) }\end{array}$ & "Benevolent Europe/IMF" \\
\hline $\begin{array}{l}\text { The consequence is that if Greece - as demanded by the new head of } \\
\text { government - has to give up a solid share of public debt, it is the taxpayers } \\
\text { in the other eurozone countries who will bear the loss. As Germany is the } \\
\text { largest economy in the eurozone, the German taxpayers will have to bear } \\
\text { the greatest loss. (Jyllands-Posten, "Greek goodbye", } 27 \text { January 2015) }\end{array}$ & $\begin{array}{l}\text { "European/German taxpay- } \\
\text { ers damaged by Greece" }\end{array}$ \\
\hline $\begin{array}{l}\text { No one can honestly speak of European cooperation and, in the same } \\
\text { breath, demand that other countries pay for years of Greek over-consump- } \\
\text { tion and corruption. The vast majority of Europeans are thoroughly tired } \\
\text { of Greece and the Greeks' twisted perception of reality. If the Greeks are } \\
\text { to regain respect, a prerequisite is that they honour all agreements made. } \\
\text { (Jyllands-Posten, "Greek goodbye", } 27 \text { January 2015) }\end{array}$ & $\begin{array}{l}\text { "Irresponsible Greeks" risk- } \\
\text { ing "European" interests }\end{array}$ \\
\hline $\begin{array}{l}\text { Tsipras belongs to the communist-left national tradition of Greece. His coali- } \\
\text { tion with the right-wing so-called Independent Greeks is logical. The most } \\
\text { extreme forces of the Civil War find each other in their rejection of a modern, } \\
\text { responsible society. (Nyholm, "The Greek nursery", } 15 \text { February 2015) }\end{array}$ & $\begin{array}{l}\text { The Syriza party is extreme } \\
\text { and equated to the far right }\end{array}$ \\
\hline $\begin{array}{l}\text { Here, the religious difference between Greece and Europe is important [...] } \\
\text { The Orthodox churches are not based on theology but on the narratives } \\
\text { of the village. Just like Islam, they are part of the mysteries of the Orient. } \\
\text { Their clergy is often poorly educated, and it is traditionally available to the } \\
\text { state: the Sultanate of Istanbul, Tsarist, Communist and Putinist Russia, } \\
\text { Ceausescu's Romania, Greece under the Colonels and now under Tsipras. } \\
\text { Intellectual coolness and critical sense are rare goods. (Nyholm, "The Greek } \\
\text { nursery", } 15 \text { February 2015) }\end{array}$ & $\begin{array}{l}\text { Greece is similar to Eastern } \\
\text { European and Asian states }\end{array}$ \\
\hline $\begin{array}{l}\text { The Greeks face an economic disaster if the result of Sunday's parliamentary } \\
\text { elections is that Greece must leave the euro [...] "A Greek euro exodus will } \\
\text { mean a } 55 \text { per cent fall in living standards, and will hit the lowest income } \\
\text { groups particularly hard. The fall in living standards is due to a sharp fall in } \\
\text { the value of a new currency of } 65 \text { per cent; in nominal value, an even deeper } \\
\text { recession of } 22 \text { per cent; in fixed prices on top of an economic downturn of } \\
14 \text { per cent. In the period from } 2009-11 \text { and an even higher unemployment } \\
\text { rate than today" notes Paul Mylonas, chief economist of the National Bank } \\
\text { of Greece, which is Greece's largest privately owned bank. He acknowledges } \\
\text { that it is very difficult to make just about exact impact calculations over a } \\
\text { Greek goodbye to the euro, as the political response pattern is in fact impos- } \\
\text { sible to predict, and it is not clear what Greece's public debt will look like after } \\
\text { the exit of the euro. (Pedersen, "A downturn worse than war", } 12 \text { June 2012) }\end{array}$ & $\begin{array}{l}\text { The election of a government } \\
\text { rejecting austerity will be cata- } \\
\text { strophic (as predicted by an } \\
\text { economist) }\end{array}$ \\
\hline
\end{tabular}

Following relevant work on class cultures and politics, we found three overarching themes developed during the second cycle of coding: 
- Moralism, regarding the direct references probing class cultures and associated with work and regimes of bourgeois entitlement (class ideology - hard-working taxpayers entitled to have a say in Greek politics).

- Culturalism, concerning the ways in which Greece, its people, and its institutions are produced - notably as deviations from the European/Danish norm (all Greeks have over-consumed and bear a twisted sense of reality; Greece is Oriental).

- Technocracy and anti-leftism, concerning the ways in which the political framework of the Greek elections were covered by $J P$.

The three main analytical themes are interrelated. Class emerges as the central denominator of these themes, because technocracy serves specific class interests in the crisiscapitalism framework, opposing the possibilities that democratic processes unfold, while the culturalist and moralist framing of the Greek crisis and Greek politics are connected to what Balibar and Wallerstein (1991) discuss as the process of the ethnicisation of the workforce through the othering of the Greek people from Europe and by defining Europe through liberalist, white-nationalist, and bourgeois notions.

\section{Moralism}

Morality constitutes an important rationale behind the "self-inflicted" Greek crisis thesis, with Greeks being charged by JP's contributors with immorality for living at the expense of "hard-working" Europeans. The Greeks are thus not entitled to the potential rewards of capitalism, such as welfare, high wages, property, and consumption, among others. Neoliberal austerity is also defended on such grounds, because it punishes the immoral and corrupt Greeks and simultaneously secures the earned privileges of Western citizens threatened by the Greeks' challenging of austerity policies. A recurrent theme of the neoliberal ideology (Hall, 2011) - the "welfare scrounger" - surfaces in the texts studied in the form of a "Greek scrounger" who deceived the EU. In the above-mentioned "Greek goodbye" article, the "European taxpayer" formulates a type of class identity that is supposedly shared by all "Europeans". While the European is honest, hardworking, prudent, law-abiding, and responsible, the Greek is not; the European helps, while the Greek deceives. Hence, the European deserves (middleclass) privileges (such as consumption, welfare, liberal rights, and a comparatively high wage, among others) and is entitled to demand the Greek to accept austerity and "honour agreements made".

Indignation, pity, and ridicule appear often in $J P$ 's coverage of the Greek crisis and its politics:

One must probably be a Greek to think that it is really cool to live up to the country's reputation, and to deceive the rest of Europe for years. From the time when the country lied, cheated and deceived itself in order to enter into the eurozone, there has been ouzofest in Athens and the surrounding area. They are not much interested to stop that party, so now they have chosen a left-wing radical for prime minister, and he has joined with a right-wing radical to form government. They quickly agreed to send the entire bill for the party to Berlin and, incidentally, demand a new batch of ouzo, of course paid by the Germans. Fortunately, investors are icy and have sent the Greek bond yields skyrocketing, accurately knowing that the 
country may have the world's most beautiful islands, but economically, it is the world's largest lottery token. (Knudsen, "Lotto token Greece”, 1 February 2015)

In the recent years, ridicule is a common practice performed by different mainstream media programmes, geared specifically toward shaming the working class and the poor (Stiernstedt \& Jakobsson, 2019). In the quoted excerpt above, the experience of an economic crisis by the Greek people is presented in simplistic terms, through a morality tale narrating the crisis as a self-inflicted case, where local commodities (such as the beverage ouzo) and consumer experience-scapes (Greece's "beautiful islands") are operationalised to explain, in a sensualistic way, the supposed profligate practices of the "other" (such as the above-mentioned "ouzofest" that occurs at the expense of Germany). A self-referential, consumerist (pseudo)knowledge of Greece is implied. For Sara Ahmed (2000: 34), the "bodily and cultural capital" of the non-Western Other is crucial for his or her estrangement. Moreover, the touristic gaze produces the habitus and subjectivity of the Other in a fetishistic form, stressing the Other's supposed fundamental difference from the Western self. Simultaneously, upper-class leanings are evident in excerpts like the following:

Crisis-free area "Spetses make up a world for themselves" says Emmanuel Vordonis. "When the crisis was at its peak this summer, we were unmoved by what was happening in the capital" claims Maria Strati. "Here everything worked as it should, and it still does. You could raise as much money as you like, there were no demonstrations but peace and quiet, and no lack of anything" [...] In Athens, we are invited home to retired shipowner and hotel investor Emmanuel Vordonis, who lives in one of Athens's suburbs [...] "I spoke to a German parliamentarian who was visiting Poseidonion. He said that if the Greek debt negotiations had been turned over to Spetses, a solution would have been found in less than a week". (Jyllands-Posten, "Greek elections" [main article], 23 September 2015)

The island of Spetses thus appears reified and ahistorical, detached from the crisis-ridden reality of Greece. Spetses specifically emerges as a "normal" place where "you" can find shelter away from Athens, where business runs "as it should", demonstrations do not occur, and calmness prevails. The sense of normality evoked is connected to bourgeois norms, tastes, and sensibilities, according to which Spetses makes an ideal Greece, where the crisis would have presumably been resolved "in less than a week".

\section{Culturalism}

The aforementioned "cultural and bodily capital" of the Greek people is assessed by JP's contributors from a Danish, or, European standard. Likewise, the politics of Greece are also judged from the vantage - and, in political terms, pragmatic point of view - of "what is good" for Europe and for Denmark. Class morality is intertwined with nationalist and neo-Orientalist signifying patterns of Western-centrism and cultural racism (Bozatzis, 2016; Ervedosa, 2017; Koutouza, 2019). "The Greek nursery" article quoted earlier implies that Greece should follow the EU's dictates to overcome its problems and become "European", indicating an essentialist difference between Europe and Greece. The core countries of European or Western capitalism come to represent the norm and the ideal, with the West idealised and sublimated as a benchmark for the periphery: 
Only fools and the truly malevolent will complain over the fact that Germany, two generations after the downfall of Nazism, is back on the global stage with a decisive influence [and] most would argue that the Germans should take on greater responsibility. Germany in the second decade of the twenty-first century is an example to follow. German thought and German rationality have ancient roots. Germany has succeeded more than ever before and we should thank her for that. (Jyllands-Posten, "Europe, congratulations", 15 February 2015)

Here, Germany is cleansed from its troubling, historically recent past (connected to its atrocious Nazi trajectory) and is celebrated as an emerging global politico-economic power. Specifically, Germany is defined in essentialist terms with its "rationality" to be founded in "ancient roots". The text legitimises Germany's hegemonic position in the EU and Germany's ordoliberal doctrines in dealing with the eurozone crisis (Dardot \& Laval, 2019). As Balibar \& Wallerstein (1991) argue, nationalism (and in a broader sense, Western-centrism) marks the divisions between the centre and the periphery, while racism functions as a mechanism unifying the centre-periphery relation. Racism arises through a practice of ethnicisation; the European (semi) peripheral state of Greece is defined as Europe's Other. For Balibar and Wallerstein (1991), ethnicisation is crucial for capitalism in order to sustain its regimes of inequality as well as pursue restructuring processes to overcome the crises that capitalist accumulation periodically meets.

Simultaneously, the "pragmatic" political position generally expressed by JP's contributors can also prompt the consideration of the potential geopolitical usefulness of Greece for Europe. The refugee and migration issue is referred to in JP's Greek 2019 elections coverage, also through the publication of far-right voices from Scandinavia:

If you rent or buy some of Greece's over 6,000 islands, the majority of which are uninhabited, you can send all asylum seekers who reach Europe there [...] He [the far-right Norwegian politician Christian Tybring-Gjedde] believes that overall the number of asylum seekers will decline because many so-called economic refugees will probably be deterred by the prospect of having to spend many months on a Greek island while their pre-sentenced case is being dealt with. "I think it's a win-win situation, because Greece is desperately lacking of money to finance its economy" he says. (Kott, "Christian Tybring-Gjedde: Buy a Greek island and send asylum seekers to it", 10 September 2015).

Greece and its crisis are seen in utilitarian terms; the crisis can be used to perform politics as a business, pushing the indebted Greece to sell "assets" (like desert islands) that Europe may need. Such predatory ideas have been previously expressed in the European liberal press during the Greek crisis and are usually related to prospects of selling Greek islands and historical monuments (Mylonas, 2019).

\section{Technocracy and anti-leftism}

Overall, the articles studied here express support for neoliberal austerity reforms. They also demonstrate deep concern for the possibility of voting in an anti-austerity government in Greece. Simultaneously, concerns are also expressed for the pre-crisis political establishment of Greece. Nevertheless, faced by the left coming to power in 2012 and 
2015, JP's contributors provide support to the conservatives (with ND being the main rival party to Syriza). The neutralised Syriza of late 2015 is perceived as a functional option, because its government will both implement neoliberal reforms and contain protests. ND's return to power in 2019 is also positively hailed. In that sense, a technocratic, pro-neoliberal reform stance is assumed, bearing anti-leftist characteristics and reflecting class anxiety toward the threat to class privileges that a leftist, anti-austerity government signifies. The Greek left is discredited from a cultural perspective, as the earlier excerpt ("The Greek nursery") showed, but also from a liberal and technocratic perspective, with the left understood as anachronistic. Politics challenging neoliberal reforms are thus sharply opposed in $J P$ :

An angry Greek student demanded answers when Prime Minister Helle ThorningSchmidt (S) yesterday attended a debate meeting at the University of Copenhagen together with EU Commission President José Manuel Barroso. The young student wanted to know how a social democratic prime minister and current EU president can accept a "neoliberal" financial pact and demand huge public savings in Greece. A couple of like-minded comrades were with him, holding a big, white and blue banner with a drawing of a large EU monster eating small, Greek unemployed people. But there was a direct reply from Thorning: "There is nothing social democratic about not balancing one's budgets or telling the youth that one is unwilling to make the necessary decisions to create jobs. What Europe has done to assist Greece is a great help. Europe has acted with great solidarity, and I hope that the Greeks will appreciate that willingness to help" Thorning said. (Boddum, "Statement to the Greeks from P.M. Thorning", 24 April 2012)

Besides being labeled as idle, corrupt, greedy, and undeserving, the Greek (leftist) protestors are also shown as irrational ("angry") and treacherous. As previously shown ("A downturn worse than war"), the potential of rejecting austerity appears as catastrophic. This serves to legitimise austerity through what van Leeuwen (2008: 119) has described as "mythopoetic reason" by launching a "(neoliberal) reforms or catastrophe" argument.

The key question is: What happens if Tsipras, with its hinterland of dogmatic Marxists, Che Guevara fans, and bright-red socialists, does not want to compromise? Or, if the rest of Europe won't? (Jensen \& Jensen, “Analysis: Europe is preparing for a new crisis", 22 January 2015)

Studies have shown that democratic and working-class mobilisations are often framed by the mainstream media as causing the disruption of "normal" affairs as well as triggering inconvenience (Kendall, 2011: 121). This makes for a "shady framing" of classstruggle (Kendall, 2011: 130), as it is represented as potentially illegitimate and surely irrational and overall dangerous to "our" wellbeing (Harkins \& Lugo-Ocando, 2018: 118). Hence, the European people are interpellated as abstaining from identifying with the Greek people, who represent everything that the Danish (and other Europeans) are not. A positive self-identity is thus assumed for the Danish (European) reader of $J P$, while hinting to the negativity the Greek Other represents.

Simultaneously, the objective language of the neoliberal reforms, developed through a technical vocabulary spoken by (economic) "experts", is also prevalent in the articles 
studied here, thus reproducing market ideologies (Harkins \& Lugo-Ocando, 2018). The objectivist language deployed to predict the outcome of the possible voting in of an anti-austerity government, and its supposedly catastrophic economic impact, provides authoritative legitimacy to $J P$ 's negative positioning towards a possible leftist electoral victory in Greece. As Harvey (2005) has noted, austerity is a form of class warfare a politics of dispossession and wealth redistribution from the bottom to the top. The economic crisis itself, and its management as an objective event by experts through moralist public repertoires, is a "class war that is relentlessly waged by the politicofinancial oligarchy" (Dardot \& Laval, 219: 26). Class politics are expressed by JP's support of neoliberal austerity, which includes welfare and wage cuts or the sacking of public employees, among others:

In total, the Greek government has cut well over a quarter of its public servants. This number is only what one can reckon. "It seems absurd, but when the crisis hit in October 2009, the Greek state did not know how many employees it had", explains Michael Arghyrou, a Greek and economics teacher at Cardiff Business. Since then, the employees were forced to register - the alternative was not to be paid wages. It rose to 1 million when the army and state-owned companies were not counted - out of a population of 11 million. When the government started counting government employees at all, it was linked to the fact that in 2009 the country was so indebted that it was no longer possible to borrow money in the international financial markets and was therefore threatened by state bankruptcy [...] He [Michael Arghyrou] acknowledges that there is still a long way to go, but: "The government was on the right track". At the same time, the labour market has been liberalised on several fronts. The average salary and the minimum wage have been significantly reduced. It is now easier - and cheaper - to hire and fire. "The reforms have increased competitiveness and strengthened the administration. For the first time, a public servant can be fired if he does not follow the rules" explains Michael Arghyrou. (Jensen \& Busk, "Fired Greeks vote to get their old work back", 25 January 2015)

Class politics further emerge through the publishing of articles openly supporting the rise of conservative politicians and the return of the right to government in Greece:

On Sunday, the Greeks elected a new prime minister, Kyriakos Mitsotakis, to match something that would have been a negative, unattractive cliché just a few years ago. Mitsotakis graduated from Harvard University, wears a suit and tie, is a former banker, belongs to the center-right wing, is financially liberal and he is even the heir of a political family. He has placed centrism as his main view, and his new government counts people from both center and center-left, as well as experts from non-political circles in addition to his own party. The language he is using, in a country intellectually dominated by Marxism for many years, echoes that used in those subversive conversations: transparency, entrepreneurship and meritocracy, instead of the clientelism and jobs-for-the-boys patronage that have marked Greek politics for decades. (Applebaum, "Brighter times after the Greek tragedy - and a new boss", 7 October 2019 [article originally for The Washington Post]) 
The celebration of the return of the bourgeois, or, conservative political establishment to government by a Washington Post contributor named Anne Applebaum, an author of various anti-leftist publications, marks the reactionary turn of today's liberalism, hostile to anything beyond the neoliberal capitalist democratic framework (Dardot \& Laval, 2019). Although Kyriakos Mitsotakis is a son of a previous prime minister for ND (a party that reigned Greece on many occasions since its founding in 1974 and that is also responsible for Greece's indebtment), elected on nationalist, anti-immigration, anti-leftist, and "law-and-order" agendas (along with neoliberal ones), he is branded by Applebaum as a "centrist technocrat" and a somewhat "fresh face" in Greek politics. Applebaum's liberalism offers a striking reversal of the history of Greek politics, presenting the left as Greece's establishment and the right as the heir of the new. Therefore, the establishing of the neoliberal (far-)right in Greece is discursively produced here through neoliberal jargon (e.g., "transparency", "entrepreneurship", and "meritocracy"), which obtains a ritualistic function, propagating neoliberal sociopolitical norms detached from acute histories and realities (Badiou, 2018).

\section{Conclusions:}

\section{Conjunctures of class, nationalism, and technocratic politics}

Our analysis shows the centrality of class politics in $J P^{\prime}$ 's Greek crisis election coverage. Specifically, class is configured with nationalist, racist, and technocratic tropes, formulating a discursive assemblage that publicly unfolds into class supremacy affirmations and is presented from a rather nation-centric point of view.

According to Balibar and Wallerstein (1991), racism is routed in the class divisions of the capitalist society, because competition and the division of labour yield structures of inequality. Class hegemony is based upon a discourse of universality that is connected to the global expansion of capitalist accumulation and the market mechanism, as well as the splitting of the labour force (e.g., between centre-periphery, male-female, and native-migrant dichotomies). In the global capitalist framework, racism arises through a pattern of ethnicisation of the workforce, which can be politically and economically useful in dividing the working class and subduing class conflict (Balibar \& Wallerstein, 1991). As our analysis shows, the widespread use of neo-Orientalist tropes deeming Greece as non- or quasi-European demonstrate the racist dimension of capitalist restructuring and class reproduction processes in the EU.

A Western-centrist realpolitik stance underlines JP's construction of Greece, with the core European nations obtaining a canonistic position in defining the identity of the peripheral Other, his or her problems, and their solution. JP's support for neoliberal austerity emerges from a nationalist and middle-class perspective, as austerity in Greece is meant to secure Danish, or European, (capitalist) interests as well as protect the European taxpayer's money provided to the Greek state in order to pay its debt owed to (mainly) German and French (privately owned) banks. Nevertheless, studies (Weiss, 2019) have shown that a middle-class position is more of an ideology today, a time characterised by low prospects of social elevation and an increasing precarisation of work where muchneeded internationalist working-class politics and cultures are largely absent. 


\section{Notes}

1. https://en.wikipedia.org/wiki/Jyllands-Posten\#cite_note-4 (accessed August 29, 2020).

2. The Gramscian concept of hegemony is deployed to describe the process where authoritative meanings become "common-sense" in a given society and authority achieves social consensus for its deeds; hegemony is never complete and can always be undermined or subverted by antagonistic discourses (Carah \& Louw, 2015).

3. The term ordoliberalism refers to the German branch of neoliberalism, which strives for an "economic constitution" that underlines the importance of a strong interventionist state to safeguard the "free market" structure (Dardot \& Laval, 2019: 40); in this respect, Slobodian (2018: 151) speaks of the emergence of an ordoglobalist institutional framework safeguarding the free market on a global level.

4. The authors read the articles in Danish (M. Noutsou has a degree in translation of Danish and Greek) and proceeded with the analysis. The specific excerpts presented here were afterwards translated into English.

\section{References}

Ahmed, S. (2000). Strange encounters: Embodied others in post-coloniality. London: Roultedge. https://doi. org/10.4324/9780203349700

Althusser, L. (2014). On the reproduction of capitalism: Ideology and ideological state apparatuses. London: Verso.

Applebaum, A. (2019, July 10). Lysere tider efter den græske tragedie- og en ny chef [Brighter times after the Greek tragedy - and a new boss]. (Article originally authored for The Washington Post). Jyllands Posten. https://jyllands-posten.dk/debat/international/ECE11494608/Lysere-tider-efter-den-græsketragedie---og-en-ny-chef/

Badiou, A. (2018). Greece and the reinvention of politics. London: Verso.

Balibar, E., \& Wallerstein, I. (1991). Race, nation, class: Ambiguous identities. Verso: London.

Basu, L. (2018). Media amnesia: Rewriting the economic crisis. London: Pluto Press.

Bickes, H., Otten, T., \& Weyman, C. L. (2014). The financial crisis in the German and English press: Metaphorical structures in the media coverage on Greece, Spain and Italy. Discourse \& Society, 25(4), 424-445. https://doi.org/10.1177/0957926514536956

Boddum, D. I. (2012, April 24). Opsang til grækeren fra Thorning [Statement to the Greeks from P.M. Thorning]. Jyllands Posten. https://jyllands-posten.dk/indland/article4678930.ece/

Bolt, M. (2011). On the turn towards liberal state racism in Denmark. e-flux, 22. https://www.e-flux.com/ journal/22/67762/on-the-turn-towards-liberal-state-racism-in-denmark/

Bozatzis, N. (2016). Cultural othering, banal Occidentalism and the discursive construction of the "Greek crisis" in global media: A case study. Suomen Anthropologi, 41(2), 47-71. https://journal.fi/suomenantropologi/article/view/59642

Buck-Morss, S. (1987). Semiotic boundaries and the politics of meaning: Modernity on Tour-a village in transition. In M. G. Raskin, \& H. J. Bernstein (Eds.), New ways of knowing: The sciences, society and reconstructive knowledge (pp. 200-236). New York: Rowman, Littlefield.

Carah, N., \& Louw, E. (2015). Media and society: Production, content and participation. London: Sage.

Crouch, C. (2011). The strange non-death of neoliberalism. London: Polity

Dardot, P., \& Laval, C. (2019). Never-ending nightmare: The neoliberal assault on democracy. London: Verso.

Doudaki, V., \& Boubouka, A. (2020). Discourses of legitimation in the news: The case of the economic crisis in Greece. London: Routledge. https://doi.org/10.4324/9780429061325

Ervedosa, C. (2017). The calibanisation of the south in the German public "euro crisis" discourse. Postcolonial Studies, 20(2), 137-162. https://doi.org/10.1080/13688790.2017.1359873

Fabry, A., \& Sandbeck, S. (2019). Introduction to special issue on "authoritarian neoliberalism". Competition \& Change, 23(2), 109-115. https://doi.org/10.1177/1024529418813827

Farkas, J., \& Neumayer, C. (2020). Mimicking news: How the credibility of an established tabloid is used when disseminating racism. Nordicom Review, 4l(1), 1-17. https://doi.org/10.2478/nor-2020-0001

Hall, S. (2011). The neoliberal revolution. Cultural Studies, 25(6), 705-728. https://doi.org/10.1080/09502 386.2011 .619886

Harkins, S., \& Lugo-Ocando, J. (2018). Poor news: Media discourses of poverty in times of austerity. London: Rowman \& Littlefield.

Harvey, D. (2005). A brief history of neoliberalism. Oxford: Oxford University Press. https://doi.org/10.1093/ oso/9780199283262.001.0001

Jacobsson, D. (2018). Business elite competition or a common concern? Journalistic representations of industrial crises in Sweden. Journalism Studies, 19(1), 105-125. https://doi.org/10.1080/146167 0X.2016.1164615 
Jensen, S. G., \& Busk, S. (2015, January 25). Fyrede grækere stemmer for at få deres gamle arbejde igen [Fired Greeks vote to get their old work back]. Jyllands-Posten. https://jyllands-posten.dk/international/ ECE7387049/fyrede-graekere-stemmer-for-at-faa-deres-gamle-arbejde-igen/

Jensen, S. G., \& Jensen, H. P. (2015, January 22). Europa forbereder sig på en ny krise [Analysis: Europe is preparing for a new crisis]. Jyllands-Posten. https://jyllands-posten.dk/international/ECE7379165/ europa-forbereder-sig-paa-en-ny-krise/

Jyllands-Posten. (2015, January 27). Græsk Farvel [Greek goodbye]. Jyllands-Posten. https://jyllands-posten. dk/debat/leder/ECE7390617/Græsk-farvel/

Jyllands-Posten. (2015, February 15). Europa Til Lykke [Europe, congratulations]. Jyllands-Posten. https:// jyllands-posten.dk/debat/leder/ECE7450723/Europa-til-lykke/

Jyllands-Posten. (2015, September 23). Græsk Valg [Greek elections] (main article). Jyllands-Posten. https:// jyllands-posten.dk/debat/leder/ECE8042985/Græsk-valg/

Kendall, D. (2011). Framing class: Media representations of wealth and poverty in America (2nd ed.). New York: Rowman \& Littlefield.

Knudsen, J. B. (2015, February 1). Lottokuponen Grækenland [Lotto token Greece]. Jyllands-Posten. https:// jyllands-posten.dk/jperhverv/ECE7399674/Erhvervsugen-på-tværs/

Kostopoulos, C. (2020). Journalism and austerity: Digitization and crisis during the Greek memoranda. Bingley, UK: Emerald.

Kott, K. (2015, September 10). Den norske politiker Christian Tybring- Gjedde: Køb en græsk ø og send asylansøgerne dertil [Christian Tybring-Gjedde: Buy a Greek island and send asylum seekers to it]. Jyllands-Posten. https://jyllands-posten.dk/international/europa/ECE8010154/Den-norske-politikerChristian-Tybring-Gjedde-Køb-en-græsk-ø-og-send-asylansøgerne-dertil/

Koutouza, D. (2019). Surplus citizens: Struggle and nationalism in the Greek crisis. London: Pluto.

Kutter, A. (2020). Construction of the eurozone crisis: Re- and depoliticising European economic integration. Journal of European Integration, 42(5), 659-676. https://doi.org/10.1080/07036337.2020.1792466

Lentin, A., \& Titley, G. (2011). The crises of multiculturalism: Racism in a neoliberal age. London: Zed Books

Lindekilde, L. (2014). The mainstreaming of far-right discourse in Denmark. Journal of Immigrant \& Refugee Studies, 12(4), 363-382. https://doi.org/10.1080/15562948.2014.894171

Mercille, J. (2013). The role of the media in fiscal consolidation programmes: The case of Ireland. Cambridge Journal of Economics, 38(2), 281-300. https://doi.org/10.1093/cje/bet068

Mondon, A., \& Winter, A. (2020). Reactionary democracy: How racism and the populist far right became mainstream. London: Verso.

Mylonas, Y. (2019). The “Greek crisis" in Europe: Race, class and politics. Leiden, Netherlands: Brill. https:// doi.org/10.1163/9789004409187

Mylonas, Y., \& Noutsou, M. (2018). The "Greferendum" in the Danish daily press. Race and Class, 59(3), 51-66. https://doi.org/10.1177/0306396817714123

Nikolopoulou, A., \& Cantera, L. M. (2016). "Exceptional," "normal” or a "myth"? The discursive construction of the "crisis" by Greek employees. Discourse \& Society, 27(5), 516-532. https://doi. org/10.1177/0957926516651364

Nyholm, P. (2015, February 15). Den græske børbehave [The Greek nursery]. Jyllands-Posten. https://jyllandsposten.dk/debat/kommentar/undervejs/ECE7450707/den-graeske-boernehave/

Ojala, M., \& Harjuniemi, T. (2016). Mediating the German ideology: Ordoliberal framing in European press coverage of the eurozone crisis. Journal of Contemporary European Studies, 24(3), 414-430. https:// doi.org/10.1080/14782804.2015.1135109

Panagiotopoulos, P., \& Sotiropoulos, D. P. (2020). Introduction: Framing Greek exoticism: History and the current crisis. In P. Panagiotopoulos, \& D. P. Sotiropoulos (Eds.), Political and cultural aspects of Greek exoticism (pp. 1-8). Cham, Switzerland: Palgrave Pivot. https://doi.org/10.1007/978-3-03019864-0 1

Pedersen, K. L. (2012, June 12). En nedtur værre end krig [A downturn worse than war]. Jyllands-Posten. https://jyllands-posten.dk/jperhverv/ECE4719947/en-nedtur-vaerre-end-krig/

Pelt, M. (2019). Images and interactions: Greece in Danish public and politics from the Revolution of 1821 to the debt crisis in the second decade of the 21 st century. In K. Winther-Jacobsen, \& N. von Eggers Mariegaard (Eds.), Proceedings of the Danish Institute at Athens, ix (pp. 141-158). Aarhus, Denmark: Aarhus University Press.

Plantzos, D. (2012). The glory that was not: Embodying the classical in contemporary Greece. Interactions: Studies in Communication \& Culture, 3(2), 147-171. https://doi.org/10.1386/iscc.3.2.147_1

Roos, J. (2019). Why not Default? The political economy of sovereign debt. Princeton, New Jersey: Princeton University Press.

Saldaña, J. (2011). The coding manual for qualitative researchers. London: Sage. 
Sepos, A. (2016). The centre-periphery divide in the eurocrisis: A theoretical approach. In J. M. Magone, B. Laffan, \& C. Schweiger (Eds.), Core-periphery relations in the European Union: Power and conflict in a dualist political economy (pp. 35-55). London: Routledge. https://doi.org/10.4324/9781315712994

Skeggs, B. (2003). Class, self, culture. London: Routledge.

Slobodian, Q. (2018). Globalists: The end of empire and the birth of neoliberalism. Cambridge, Massachusetts: Harvard University Press.

Sotiropoulos, D. P., John Milios, J., \& Lapatsioras, S. (2013). A political economy of contemporary capitalism and its crisis: Demystifying finance. London: Routledge. https://doi.org/10.4324/9780203771297

Stahl, R. (2019). Neoliberalism with Scandinavian characteristics: The slow formation of neoliberal commonsense in Denmark [Conference presentation]. SASE Annual Meeting: Society of the Advancement of Socio-Economics, New York, USA. https://www.academia.edu/39733794/Neoliberalism_with_Scandinavian_characteristics_The_slow_formation_of_neoliberal_common_sense_in_Denmark

Stamou, A. G. (2018). Fictionalization of Germanness in the times of Greek crisis: Deconstructing the "two strangers" frame in TV sketch comedies. Journal of Multicultural Discourses, 13(4), 377-397. https:// doi.org/10.1080/17447143.2019.1579823

Statista. (2019). Ranking of national daily newspapers in Denmark in 1st half of 2019, by number of weekly readers. https://www.statista.com/statistics/595926/ranking-of-national-daily-newspapers-in-denmarkby-number-of-readers/

Stiernstedt, F., \& Jakobsson, P. (2019). Defusing the male working class: Populist politics and reality television. European Journal of Cultural Studies, 22(5-6), 545-562. https://doi.org/10.1177/1367549418786423 van Dijk, T. A. (1988). News as discourse. Hillsdale, New Jersey: Lawrence Erlbaum Associates.

van Dijk, T. A. (1991). Racism and the press. London: Routledge. https://doi.org/10.4324/9781315682662 van Leeuwen, T. (2008). Discourse and practice: New tools for critical discourse analysis. Oxford: Oxford University Press. https://doi.org/10.1093/acprof:oso/9780195323306.001.0001

Weiss, H. (2019). We have never been middle class: How social mobility misleads us. London: Verso.

Y1lmaz, F. (2016). How the workers became Muslims: Immigration, culture, and hegemonic transformation in Europe. Ann Arbor, Michigan: University of Michigan Press. https://doi.org/10.3998/mpub.8857103

(C) 2021 Nordicom and respective authors. This is an Open Access work licensed under the terms of the Creative Commons Attribution-NonCommercial-NoDerivatives 4.0 International Public licence (CC BY-NC-ND 4.0). To view a copy of the licence, visit https://creativecommons.org/ licenses/by-nc-nd/4.0/ 